\title{
Ischemia Induces a Translocation of the Splicing Factor tra2- $\beta 1$ and Changes Alternative Splicing Patterns in the Brain
}

\author{
Rosette Daoud, ${ }^{1}$ Günter Mies, ${ }^{2}$ Agata Smialowska, ${ }^{1}$ Laszlo Oláh, ${ }^{1}$ Konstantin-Alexander Hossmann, ${ }^{2}$ and \\ Stefan Stamm ${ }^{1}$ \\ 1/nstitute of Biochemistry, University of Erlangen-Nurenberg, 91054 Erlangen, Germany, and 2Max-Planck-Institute for \\ Neurological Research, 50931 Köln, Germany
}

\begin{abstract}
Alternative splice-site selection is regulated by the relative concentration of individual members of the serine-arginine family of proteins and heterogeneous nuclear ribonucleoproteins. Most of these proteins accumulate predominantly in the nucleus, and a subset of them shuttles continuously between nucleus and cytosol. We demonstrate that in primary neuronal cultures, a rise in intracellular calcium concentration induced by thapsigargin leads to a translocation of the splicing regulatory protein tra2- $\beta 1$ and a consequent change in splice-site selection. To investigate this phenomenon under physiological conditions, we used an ischemia model. Ischemia induced in the brain causes a cytoplasmic accumulation and hyperphosphorylation of tra2- $\beta 1$. In addition, several of the proteins binding to tra2-
\end{abstract}

$\beta 1$, such as src associated in mitosis 68 and serine/argininerich proteins, accumulate in the cytosol. Concomitant with this subcellular relocalization, we observed a change in alternative splice-site usage of the $\mathrm{ICH}-1$ gene. The increased usage of its alternative exons is in agreement with previous studies demonstrating its repression by a high concentration of proteins with serine/arginine-rich domains. Our findings suggest that a change in the calcium concentration associated with ischemia is part of a signaling event, which changes pre-mRNA splicing pathways by causing relocalization of proteins that regulate splice-site selection.

Key words: alternative pre-mRNA processing; SR proteins; ischemia; phosphorylation; calcium; stroke
Advances in the human genome project have shown that almost all human genes contain introns that are removed during premRNA processing. An estimated $47-60 \%$ of genes contain exons that can be used alternatively (Lander et al., 2001; Modrek et al., 2001). Alternative pre-mRNA processing plays a key role in generating a vast proteome of $150,000-1,000,000$ proteins from the surprisingly low number of 30,000-40,000 genes (Lander et al., 2001; Hodges et al., 2002). Alternative splicing pathways can be regulated (e.g., during development) in response to cellular activity, in response to stress, during programmed cell death, or as a result of a pathological state (Daoud et al., 2000; Stoss et al., 2000; Akker et al., 2001; Grabowski and Black, 2001; Soreq and Seidman, 2001).

Current models indicate that a fine-tuned balance of ciselements and trans-acting factors is responsible for proper alternative splice-site selection (Grabowski, 1998; Elliot, 2000; Smith and Valcarcel, 2000). The major cis-elements comprise 5' and 3' splice sites and auxiliary sequence elements near them that act as enhancers or silencers. Those auxiliary elements bind to two major groups of proteins, proteins with serine-arginine-rich domains (SR proteins) (Fu, 1995; Manley and Tacke, 1996; Graveley, 2000) and heterogeneous nuclear ribonucleoproteins (hnRNPs) (Weighardt et al., 1996), which can change the recognition of splice sites because both SR proteins and hnRNPs bind to components of the spliceosome (Tian and Maniatis, 1993;

\footnotetext{
Received Nov. 2, 2001; revised March 7, 2002; accepted April 19, 2002.

This work was supported by the European Union (Bio4-98-0259) and the Deutsche Forschungsgemeinschaft (Sta399/2-1 and 3/1 and SFB473/C8).We thank Gregor Eichele, Annette Gärtner, and Peter Stoilov for discussions, J. Chalcroft for artwork, and Manuela Olbrich for technical assistance.

Correspondence should be addressed to Stefan Stamm at the above address. E-mail: stefan@stamms-lab.net.

Copyright (C) 2002 Society for Neuroscience $\quad 0270-6474 / 02 / 225889-11 \$ 15.00 / 0$
}

Hertel et al., 1997; Liu et al., 1998, 2000; Chew et al., 1999). As a result, alternative exons can be regulated by modulation of the concentration of SR proteins and hnRNPs (Cáceres et al., 1994; Wang and Manley, 1995; Manley and Tacke, 1996) that have a characteristic concentration in a given tissue (Kamma et al., 1995; Hanamura et al., 1998).

Stroke is a leading cause of morbidity and mortality in industrialized countries, imposing an enormous economic burden on the families of the patients and the society overall (Taylor et al., 1996). The trigger of stroke is a focal reduction of blood flow below the threshold required to maintain oxidative respiration (Hossmann, 1994). However, in the vicinity of this primary necrotic lesion, secondary disturbances evolve and gradually expand and produce additional injury, the amount of which may outweigh that of the primary impact (Heiss et al., 1994; Gyngell et al., 1995). The reasons for this delayed ischemic injury are only partly understood. Gene expression analysis suggests that $>1000$ genes are either upregulated or downregulated by more than a factor of four, and that many of these may be directly involved in the injury propagation (Trendelenburg et al., 2000). This integrated pattern of genomic dysregulation would also be complicated by missplicing or alternative splicing; however, until now, this question has not been addressed.

We demonstrate that as a reaction to stroke, nuclear proteins regulating pre-mRNA splicing change their subcellular distribution and accumulate in the cytosol. Concomitantly, alternative splice-site selection of the $\mathrm{ICH}-1$ gene is changed, suggesting that a change in alternative splicing patterns contributes to the outcome of stroke.

\section{MATERIAL AND METHODS}

Primary neuron cultures. Cortex regions were dissected from embryonic day 19 rats. The tissue was digested for 20 min with $500 \mu \mathrm{g}$ of papain 
(Sigma, St. Louis, MO) in the presence of $10 \mathrm{~mm}$ glucose, $1 \mathrm{mg} / \mathrm{ml}$ bovine serum albumin, and $10 \mu \mathrm{g}$ DNase in PBS. The cells were carefully dissociated with a pipette, and the mixture was centrifuged at $1000 \times g$ for $5 \mathrm{~min}$. The cells were resuspended in DMEM containing $15 \%$ fetal calf serum and were plated onto poly-DL-ornithine-precoated six well dishes (Nunc, Naperville, IL). The density of plating was $1 \times 10^{6}$ cells/ well. Approximately $1 \mathrm{hr}$ after plating, the medium was changed to a serum-free complete medium (Stamm et al., 1993) and the cells were cultured at $37^{\circ} \mathrm{C}$ in a $10 \% \mathrm{CO}_{2}$ humidified atmosphere. After 1 week, cells were subjected to treatment with thapsigargin $(1 \mu \mathrm{M})$ (Sigma) for 1-24 hr.

Immunostaining. For immunohistochemistry, C57BL/6 mice were subjected to transient focal cerebral ischemia for $1 \mathrm{hr}$ and the animals were immediately frozen in situ in liquid nitrogen at various recirculation times. Brains were then removed in a cold temperature cabinet at $-20^{\circ} \mathrm{C}$. Coronal cryostat sections were cut at $20 \mu \mathrm{m}$, placed on gelatinized slides, and stored at $-20^{\circ} \mathrm{C}$. Sections were fixed in $4 \%$ paraformaldehyde in PBS for $30 \mathrm{~min}$ and were washed three times in PBS. They were preincubated for $1 \mathrm{hr}$ in $3 \%$ NGS with $0.5 \%$ Triton $\mathrm{X}-100$ in PBS at room temperature and were then incubated overnight at $4^{\circ} \mathrm{C}$ with the tra2- $\beta 1$ antiserum (1:500), anti-monoclonal antibody (mAb)104 (1:1) (American Type Culture Collection, Manassas, VA), anti-src associated in mitosis (SAM)68 (Santa Cruz Biotechnology, Santa Cruz, CA) (1:50), anti-rat SAM68-like molecule-2 (rSLM-2) (1:100) (Stoss et al., 2001), and anti-cleaved caspase-3 (New England Biolabs, Beverly, MA) in PBS containing $0.3 \%$ NGS and $0.5 \%$ Triton X-100. After three washes in PBS, the sections were incubated with the secondary $\mathrm{Cy} 3$-fluorochrome-conjugated goat anti-rabbit or IgG mouse antibody (Jackson ImmunoResearch, West Grove, PA). For anti-mAb104, we used the Cy3 anti-mouse IgM antibody at a dilution of 1:200 in PBS for $2 \mathrm{hr}$. Next, the sections were counterstained with $0.5 \mu \mathrm{g} / \mathrm{ml} \mathrm{4',6-diamidino-2-phenylindole} \mathrm{(DAPI;} \mathrm{Sigma,}$ Deisenhofen, Germany) in PBS for 10 min or with 1:200 of the nuclear Nissl counterstain (Neuro Trace Green Fluorescent Nissl Stain; Molecular Probes; Leiden, The Netherlands), washed again three times with PBS, and coverslipped with Gel-Mount (Biomeda Corporation, Frankfurt, Germany).

Immunofluorescence images were obtained using confocal laser microscopy. The general overview of one section was obtained by scanning the entire section with a CCD camera (Leica, Nussloch, Germany) and a scanner integrated to the microscope. The quantification of the tra2positive cells was performed by Neurolucida (Leica).

Reverse transcription-PCR. Total RNA was extracted from the striatal region of mice by the guanidinium thiocyanate method, as described previously (Chomczynski and Sacchi, 1987). For reverse transcription (RT)-PCR, cDNA was made from $1 \mu \mathrm{g}$ of total RNA using $\mathrm{H}^{-}$-Moloney murine leukemia virus reverse transcriptase (Invitrogen, San Diego, CA), $5 \mathrm{~mm}$ random primers (Promega, Madison, W I), $0.1 \mathrm{~mm}$ deoxyNTPs, $10 \mathrm{U}$ of RNasin, and $10 \mathrm{~mm}$ dithiothreitol. The reactions were performed using the following primers: ICHrev, AATTCAAGGGACGGGTCATG; ICHfor, ATGCTAACTGTCCAAGTCTA.

The PCR conditions used were denaturation at $94^{\circ} \mathrm{C}$ for $2 \mathrm{~min}$. Forty cycles of denaturation $\left(94^{\circ} \mathrm{C}\right.$ for $\left.30 \mathrm{sec}\right)$, annealing $\left(55^{\circ} \mathrm{C}\right.$ for $\left.30 \mathrm{sec}\right)$, and elongation $\left(72^{\circ} \mathrm{C}\right.$ for $\left.30 \mathrm{sec}\right)$ were then performed.

The final elongation was performed at $72^{\circ} \mathrm{C}$ for $10 \mathrm{~min}$. PCR products were resolved on $2 \%$ agarose gels and were quantified with the enhanced analysis system of Herolab (Wiesloch, Germany).

Experimental groups. Experimental procedures were conducted with governmental approval according to the National Institutes of Health guidelines for the care and use of laboratory animals. Adult male C57BL/6 mice weighing 20-28 gm were subjected to transient focal ischemia by middle cerebral artery (MCA) occlusion for $1 \mathrm{hr}$ without reperfusion or with recirculation for 3,6 , and $24 \mathrm{hr}(n=3-4$ animals per group).

Animal surgery. Animals were anesthetized with $1 \%$ halothane $(30 \%$ $\mathrm{O}_{2}$, remainder $\mathrm{N}_{2} \mathrm{O}$ ). Rectal temperature was maintained between 36.5 and $37.0^{\circ} \mathrm{C}$ using a feedback-controlled heating system. During the experiments, cortical blood flow was measured by laser Doppler flowmetry (LDF) using a $1 \mathrm{~mm}$ fiberoptic probe (Perimed, Stockholm, Sweden) positioned on the intact skull over the MCA territory to monitor LDF changes during ischemia and after the onset of reperfusion. Focal cerebral ischemia was induced using an intraluminal filament technique (Hata et al., 1998). Briefly, a midline neck incision was made and the left common and external carotid arteries were isolated and ligated. A microvascular clip (FE691; Aesculap, Tuttlingen, Germany) was temporarily placed on the internal carotid artery. An 8-0 nylon monofilament (Ethilon; Ethicon, Norderstedt, Germany) coated with silicon resin (Xan- topren; Bayer Dental, Osaka, Japan) was introduced through a small incision into the common carotid artery and was advanced $9 \mathrm{~mm}$ distal to the carotid bifurcation for occlusion of the MCA. The size of the thread (150-200 $\mu \mathrm{m}$ ) was matched to the body weight to ensure reproducible vascular occlusion (Hata et al., 1998). After $60 \mathrm{~min}$, reperfusion was initiated by withdrawal of the thread. Twenty minutes later, anesthesia was discontinued and animals were placed into their home cages. Experiments were terminated under halothane anesthesia by in situ freezing of animals. Tissue was stored at $-80^{\circ} \mathrm{C}$ until additional processing.

Regional measurement of ATP. Brains were removed in a cold temperature cabinet $\left(-20^{\circ} \mathrm{C}\right)$ and cut into $20-\mu \mathrm{m}$-thick cryostat sections. Coronal sections from the striatal level were mounted on coverslips for ATP bioluminescent imaging and on gelatin-coated slides for immunohistochemistry. For regional ATP measurement, coverslip-mounted in situ frozen sections were freeze-dried and coated with a layer of frozen reaction mix containing the enzymes, coenzymes, and cofactors necessary for evoking ATP-specific bioluminescence (Kogure and Alonso, 1978). The tissue/enzyme bilayer was thawed, and light emission was recorded with a cooled CCD camera (SensiCam) using the PC software SensiControl (PCO CCD Imaging, Kelheim, Germany).

Western blot. Proteins for immunoblotting were prepared from the striatal region of control and ischemic hemispheres by homogenizing $0.25 \mathrm{gm}$ of tissue in $1 \mathrm{ml}$ of sample buffer (60 mM Tris/HCl, pH 6.8, 2\% SDS, 0.1 M dithiothreitol). Boiling and centrifugation were then performed.

Protein $(30 \mu \mathrm{g})$ was subjected to SDS-PAGE $(12 \%)$, as described previously (Laemmli, 1970), transferred onto ECL membranes (Amersham Biosciences, Arlington Heights, IL), incubated with rabbit tra2 antiserum (Daoud et al., 1999), diluted 1:2000 in 1× NET (150 mM $\mathrm{NaCl}, 5 \mathrm{mM}$ EDTA, $50 \mathrm{mM}$ Tris, pH 7.5, 0.05\% Triton $\mathrm{X}-100$, and $0.25 \%$ gelatine) $/ 2.5 \times$ gelatin, and detected with an anti-rabbit antiserum coupled to horseradish peroxidase (Amersham Biosciences) (1:3000).

\section{RESULTS}

\section{Blocking the sarco-endoplasmatic reticulum $\mathrm{Ca}^{2+}$ - ATPases alters the subcellular localization of the splicing regulatory protein tra2- $\beta 1$ in primary neurons}

Previous studies have shown that an induction of the mitogenactivated protein kinase kinase, 38 kDa (MKK-p38) pathway causes a cytoplasmatic accumulation of the splicing regulatory proteins hnRNP A1 and splicing factor 2 (SF2)/alternative splicing factor (ASF) (van der Houven van Oordt et al., 2000). We previously reported a change in splicing patterns after neuronal stimulation (Daoud et al., 1999) and wanted to investigate whether the splicing regulatory protein tra2- $\beta 1$ changes its intracellular localization when intracellular calcium levels are elevated. An increase in intracellular calcium was evoked in primary neuronal cultures by blocking the sarco-endoplasmatic reticulum $\mathrm{Ca}^{2+}$-ATPases with thapsigargin (Treiman et al., 1998). As shown in Figure 1, thapsigargin treatment causes a change in the subcellular localization of endogenous tra2- $\beta 1$ after $1 \mathrm{hr}$ in primary rat cortical cultures. After $6 \mathrm{hr}$, tra2- $\beta 1$ immunoreactivity can no longer be detected in the majority of nuclei (Fig. 1, $6 \mathrm{hr}$ ), whereas application of the solvent (DMSO) had no effect. In thapsigargin-treated cells, it could clearly be seen that tra2- $\beta 1$ immunoreactivity was detectable in the neurites. Similar results were obtained when SR proteins were detected with the pananti-SR antibody mAb104 (data not shown). Previous work demonstrated that activation of MKK-p38 can cause a relocalization of splicing factors. However, we were not able to detect phosphorylation of MKK-p38, which would be indicative for the activation of the MKK-p38 kinase pathway (data not shown).

We conclude that a change in the intracellular $\mathrm{Ca}^{2+}$ concentration, evoked by thapsigargin, causes an accumulation of tra2- $\beta 1$ and SR proteins in the cytosol of primary neurons. 

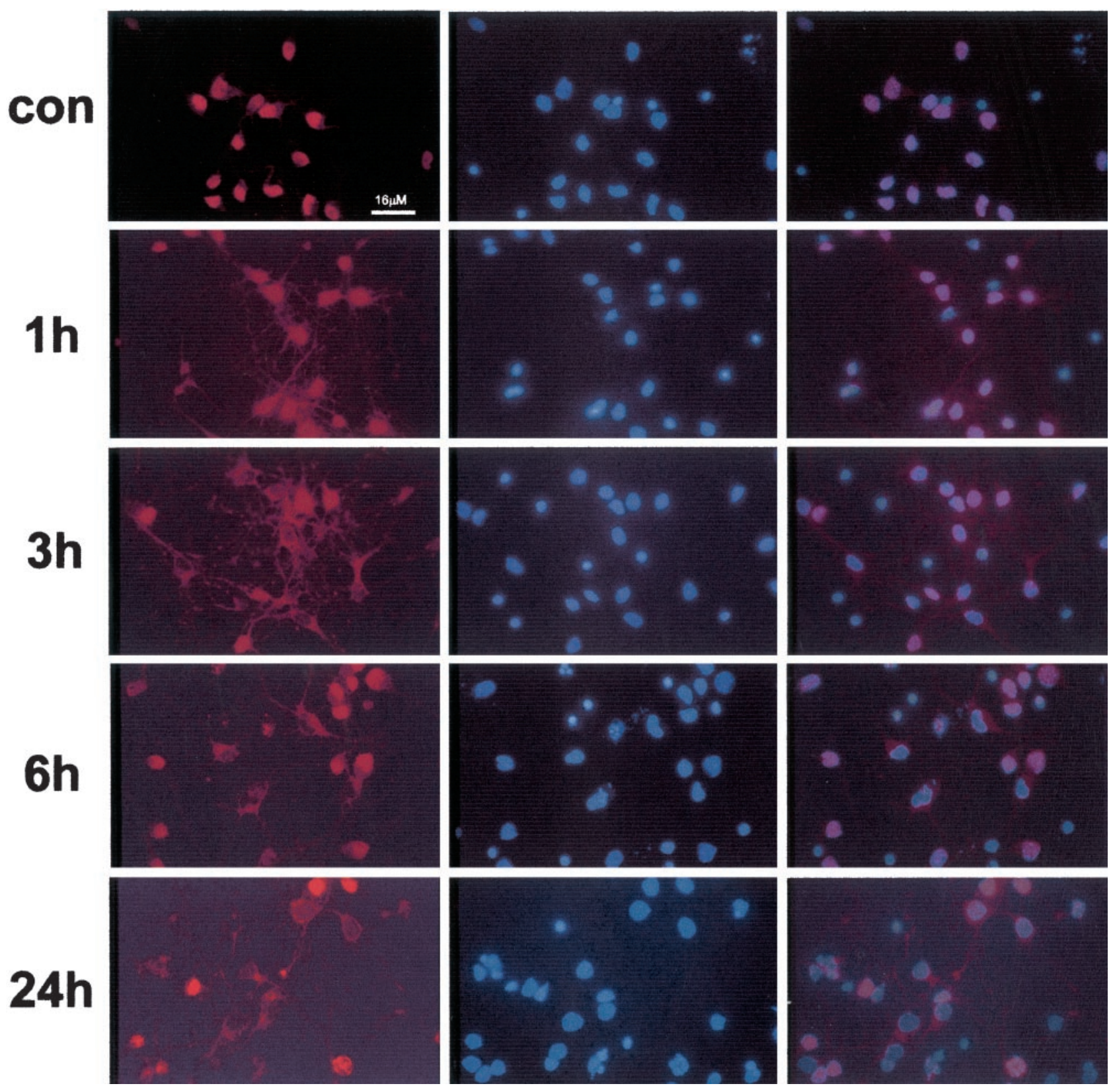

Figure 1. Intracellular localization of tra2- $\beta 1$ in primary neuronal cultures after treatment with thapsigargin. Primary cortical neurons were subjected to treatment with thapsigargin. The intracellular localization of tra2- $\beta 1$ was determined by immunocytochemistry. The control (con) shows cells that were treated with DMSO only for $3 \mathrm{hr}$. Other time points looked similar. Left column, tra2- $\beta 1$ is detected with a tra2- $\beta 1$ antiserum. Middle column, DAPI staining of the same field. Right column, Overlay of the tra2- $\beta 1$ and DAPI staining. The numbers on the left indicate the time of thapsigargin treatment.

\section{Thapsigargin treatment changes the alternative} splicing patterns of $\mathrm{ICH}-1$ in primary neuronal cultures

Next, we tested whether the thapsigargin-induced relocation of splicing factors changes alternative splicing patterns. Cells were treated with thapsigargin for $1-24 \mathrm{hr}$, and the splicing patterns of the endogenous $I \mathrm{CH}-1$ gene were determined. As shown in Figure 2 , we observed an approximately fourfold increase in the ICH-1S form. These data indicate that a change in intracellular calcium evoked by thapsigargin can affect pre-mRNA processing pathways.

\section{The number of tra2- $\beta 1$-positive nuclei decrease in an} ischemic focus

Calcium release from intracellular stores is the major cause for calcium-related neuronal injury during cerebral ischemia (Pas- chen et al., 1996; Grondahl et al., 1998). We therefore asked whether a translocation of splicing factors is also observed under such pathological conditions and applied an established ischemia paradigm (Hara et al., 1996; Hata et al., 1998). In this model, mice were subjected to 60 min of suture occlusion of the MCA and then recirculation for $0,3,6$, and $24 \mathrm{hr}$. The immediate pathophysiological response of this treatment was a focal depletion of ATP that defines the ischemic focus. To localize the ischemic focus, tissue sections were analyzed with ATP-specific bioluminescence (Kogure and Alonso, 1978). As expected, ATP was depleted in the striatum at the end of $1 \mathrm{hr}$ of MCA occlusion, but recirculation resulted in the return of ATP $3 \mathrm{hr}$ after ischemia. After $24 \mathrm{hr}$ of recirculation, a focus of secondary ATP depletion developed in 

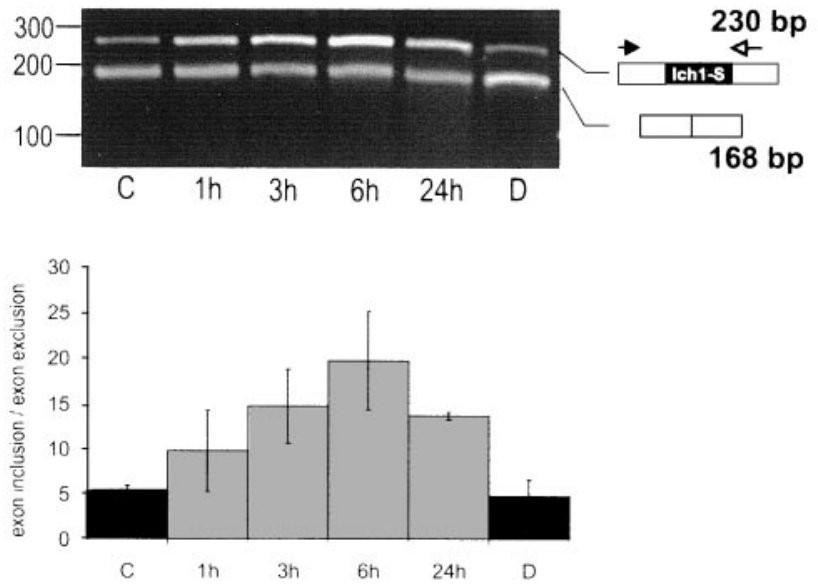

Figure 2. Thapsigargin treatment changes alternative splicing patterns. Primary cortical neurons were subjected to treatment with thapsigargin, and the splicing pattern of the endogenous $\mathrm{ICH}-1 \mathrm{~S}$ gene was determined. $C$, Control receiving DMSO for $3 \mathrm{hr}$. $D$, Control receiving DMSO for 24 $\mathrm{hr}$. Thapsigargin treatment times are indicated at the bottom of each panel. A representative agarose gel of the RT-PCR products is on the left. The drawing to the right shows schematically the primer localization and the structure of the PCR products. The statistical evaluation of independent experiments is shown the the bottom panel. Error bars indicate the SD from at least four different experiments. Arrows indicate the location of the primers used for PCR.

the center of the MCA territory (Fig. 3A). We analyzed the expression of a critical splicing regulatory protein, human tra2- $\beta 1$ (Beil et al., 1997), after the ischemic insult. Immunohistochemistry with an antiserum specific for tra2- $\beta$ revealed an altered staining pattern in the ischemic focus after 6 and $24 \mathrm{hr}$ of recirculation. In particular, we noticed a decrease in the number of tra2- $\beta 1$-positive nuclei (Fig. $3 B$; see Fig. 5 for larger magnification). The presence and integrity of the nuclei were confirmed by DAPI (Fig. $3 C$ ) and Nissl (see Fig. $5 E$ ) staining that also allowed us to quantify the tra2- $\beta$-positive nuclei. We determined the fraction of nuclei that were positive for tra $2-\beta 1$ by comparing tra2- $\beta 1$ immunoreactivity with the nuclear DAPI staining, both in the ischemic side and in the contralateral control side (Fig. 3D). As expected, only $\sim 70 \%$ of the cells in the brain expressed tra2- $\beta 1$, which is in agreement with our previous findings (Daoud et al., 1999). After $1 \mathrm{hr}$ of transient ischemia, this fraction dropped to 50 and $40 \%$ after 6 and $24 \mathrm{hr}$ of recirculation, respectively. In contrast, no change in the amount of tra2- $\beta 1$ positive nuclei was observed in the unaffected contralateral side and in cortical regions distant to the territory supported by the MCA. In contrast, the ischemic focus was not visible when the sections were stained for rSLM-2 (Stoss et al., 2001) (data not shown) (see Fig. 6C).

We conclude that after transient focal cerebral ischemia, the number of tra2- $\beta 1$-positive nuclei decreases in the cells located in the ischemic focus.

\section{Ischemia causes hyperphosphorylation of tra2- $\beta 1$ and a change in its subcellular distribution}

Similar to other SR proteins, tra2- $\beta 1$ exists in different phosphorylated forms that can be distinguished by PAGE. We investigated whether ischemia alters the phosphorylation pattern (Daoud et al., 1999). Using the ATP depletion as a marker for the ischemic focus, we isolated tissue from the ischemic focus and the contralateral control side from adjacent sections and analyzed protein extracts by Western blot using an antiserum against tra2- $\beta 1$.
As demonstrated previously, the antiserum detects two forms, a slow-migrating hyperphosphorylated form and a fast-migrating hypophosphorylated form (Daoud et al., 1999). The ischemic insult leads to an increase in the hyperphosphorylated form after 6 and $24 \mathrm{hr}$ (Fig. 4). In addition, no change in the total tra2- $\beta 1$ level was observed when the tra2- $\beta 1$ signal was compared with actin and histone signals (data not shown).

We then stained the tissues with an antiserum against tra2- $\beta 1$ and inspected the cells of the ischemic focus under higher magnification. Similar to the situation with primary neuronal culture, we found that with the ischemic focus, tra2- $\beta 1$ immunoreactivity decreased in the cell nuclei, whereas immunoreactivity became detectable in the cytoplasma and the neurites of cells (Fig. 5). These changes could be observed in both the periphery and the center of the focus. As expected, in ischemic animals without recirculation (Fig. 5, $0 \mathrm{hr}$ ), tra2- $\beta 1$ could be detected only in nuclei, where it was localized in a speckled pattern. In contrast, after $6 \mathrm{hr}$ of recirculation, tra2- $\beta 1$ immunoreactivity could be detected in the cytoplasma surrounding the nucleus (Fig. 5, $6 \mathrm{hr}$ ) and the residual nuclear staining became more diff use. Finally, 24 after MCA occlusion, most tra2- $\beta 1$ immunoreactivity disappeared from the nucleus and was located in the surrounding cytosol (Fig. 5, $24 \mathrm{hr}$ ). At that time, tra2- $\beta 1$ could be detected even in neurites emerging from the neurons. Staining with Neuro Trace Nissl confirmed the integrity of the nuclei in cells showing a cytosolic accumulation of tra2- $\beta 1$ (Fig. $5 E$ ).

We conclude that transient ischemia induces a hyperphosphorylation of tra2- $\beta 1$. This phosphorylation occurs several hours after the ischemic insult and is accompanied by a translocation of tra2- $\beta 1$ from the nucleus to the cytosol.

\section{After ischemia, proteins interacting with tra2- $\beta 1$ translocate from the nucleus}

Previous work shows that pre-mRNA processing occurs in a large macromolecular complex in vivo (Corden and Patturajan, 1997; McCracken et al., 1997), which has been named "transcriptosomal complex" or "RNA factory." Several studies have shown previously that tra2- $\beta 1$ interacts with components of this complex, among them the SR proteins SRp75, SRp55, SRp40, SF2/ASF, and splicing component $35 \mathrm{kDa}$ (SC35) (Nayler et al., 1998a), the hnRNP-like protein scaffold attachment factor B (Nayler et al., 1998b), the SR protein kinases clk1-clk4 (Nayler et al., 1997), the signal transduction and activation of RNA (STAR) protein SLM2/tra2-STAR (Venables et al., 1999), and hnRNP G-related protein (Venables et al., 2000). Several SR proteins shuttle continuously between the nucleoplasma and the cytosol, which is suggestive of cytosolic modification of the proteins as well as additional roles of these proteins in nuclear export of mature mRNA and in translation (Cáceres et al., 1998). In addition, SAM68 was shown to leave the nucleus after viral infections (McBride et al., 1996). We therefore determined whether tra2- $\beta$ interacting proteins change their subcellular localization after ischemia as well.

First, we used the mAb104 antibody that recognizes a phosphoepitope present in all members of the SR protein family (Neugebauer et al., 1995). As shown in Figure 6 $\mathrm{A}$, mAb104 immunoreactivity translocates from the nucleus to the cytosol similarly to tra2- $\beta 1$. However, this change in subcellular localization occurs earlier than the one observed with tra2- $\beta 1$, because a significant number of cells showed mAb104 immunoreactivity in cytosol and neurites as early as $3 \mathrm{hr}$ after reoxygenation.

We subsequently tested the ubiquitously expressed STAR pro- 

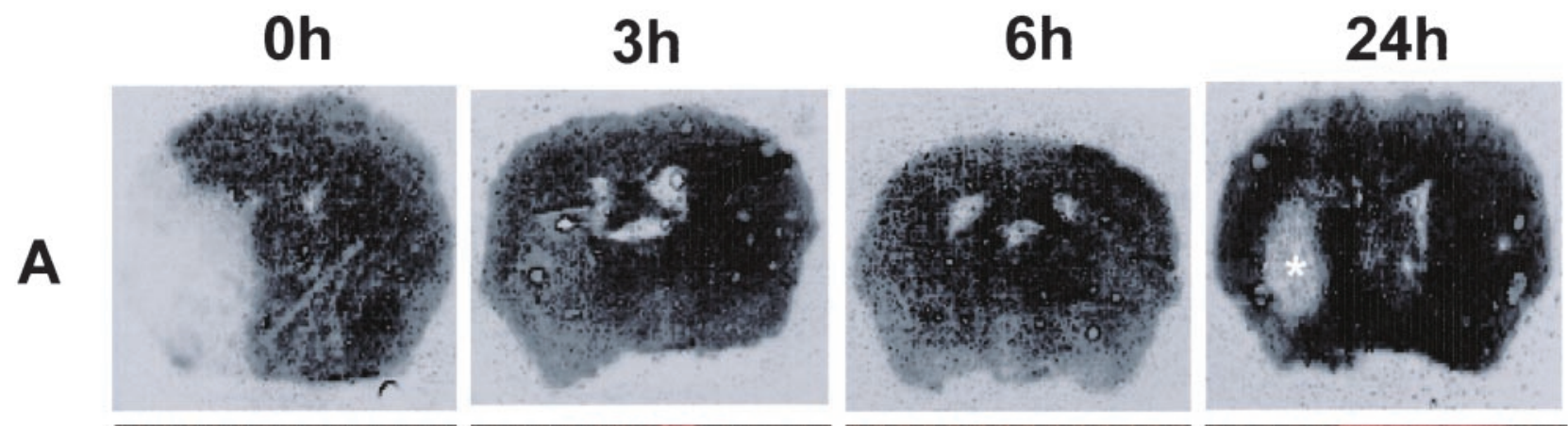

ATP
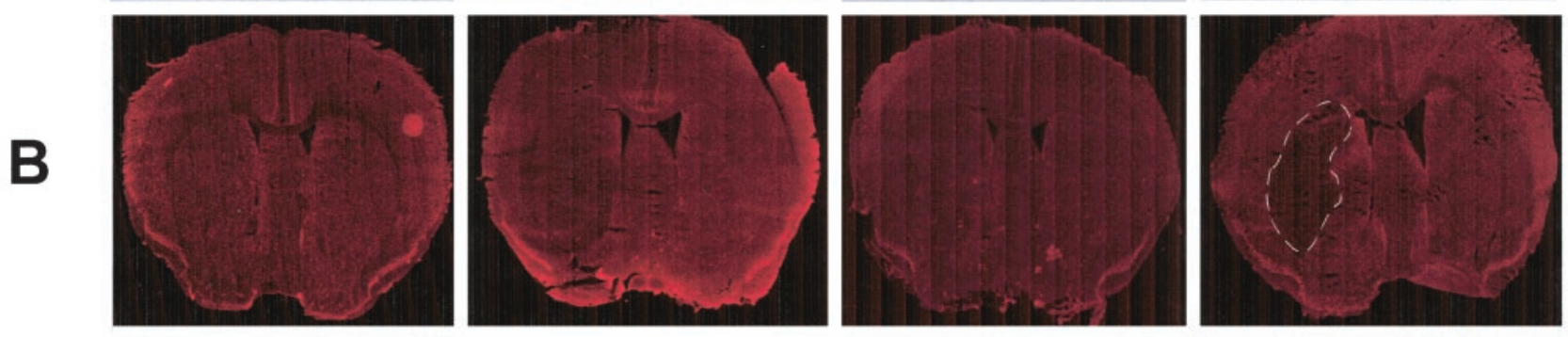

tra2beta
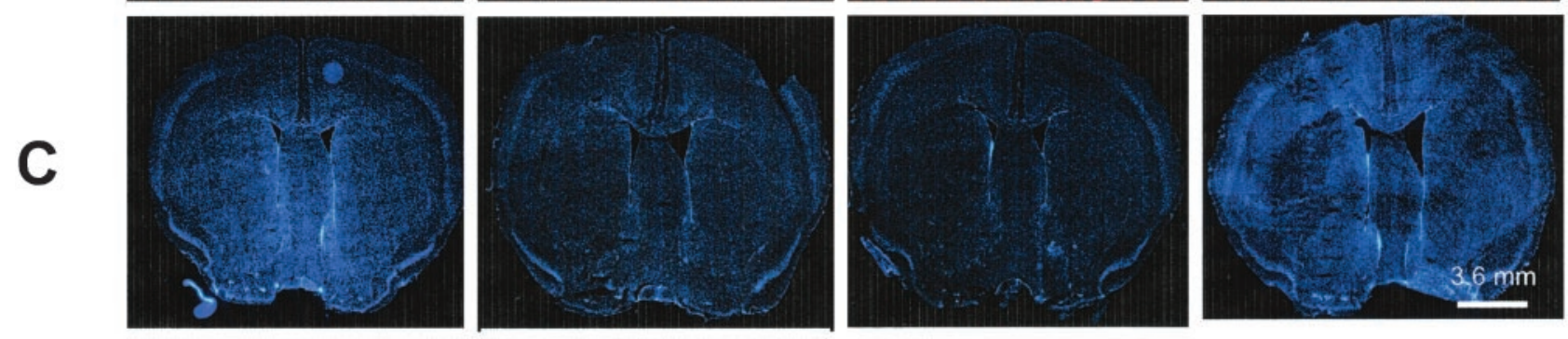

dapi
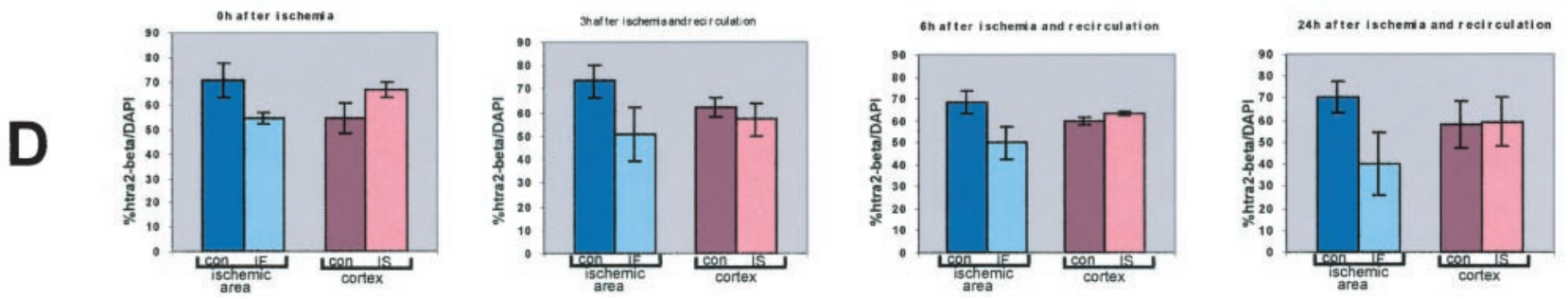

Figure 3. tra2- $\beta 1$ immunoreactivity in an ischemic focus. Coronal mouse brain sections after $1 \mathrm{hr}$ of transient focal cerebral ischemia and reperfusion are shown. The columns correspond to $0,3,6$, and $24 \mathrm{hr}$ after recirculation. $A$, Determination of the regional ATP content in tissue sections. A luciferase assay was used. Dark areas indicate normal ATP levels. ATP was depleted after $1 \mathrm{hr}$ of ischemia ( $0 \mathrm{hr}$ of recirculation), returned to normal levels at the time of recirculation until $6 \mathrm{hr}$ after ischemia, and developed secondary energy failure that was clearly visible at $24 \mathrm{hr}$ after ischemia (asterisk). $B$, tra2- $\beta 1$ expression was determined in parallel sections by immunohistochemistry. Changes in the caudate-putamen were already detected at $6 \mathrm{hr}$ and were clearly evident $24 \mathrm{hr}$ after ischemia. The area showing relocalization of tra2- $\beta 1$ is marked by a dotted line for the 24 hr time point. Cells from this area are enlarged in Figure 5. C, DAPI staining of a parallel section shows the integrity of the nuclei. $D$, Quantification of tra2- $\beta 1$-positive cells in the ischemic focus (blue) and in the unaffected cortex regions (red). con, Area of contralateral side corresponding to the ischemic focus; $I F$, area of ischemic focus; con, cortical region of the contralateral side; $I S$, cortical region on the ischemic side.

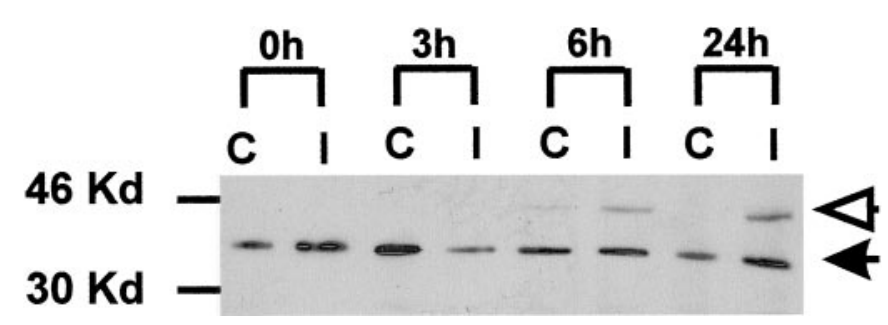

Figure 4. tra2- $\beta 1$ is hyperphosphorylated after ischemia. Western blot analysis of tissue derived from the ischemic focus $(I)$ and from the unaffected contralateral side that serves as a control $(C)$ is shown. The reoxygenation time is indicated at the top. The open arrow indicates the hyperphosphorylated form, and the closed arrow points to the hypophosphorylated form. Molecular mass is indicated on the left. tein family member SAM68 (Taylor et al., 1995; Vernet and Artzt, 1997) and found that it also translocated from the nucleus to the cytosol (Fig. 6B). Finally, we tested the related STAR protein family member rSLM-2 (Di Fruscio et al., 1999; Stoss et al., 2001). rSLM-2 regulates splice-site selection by binding to purine-rich enhancers and was postulated to be a link between signal-transduction pathways and pre-mRNA processing (Stoss et al., 2001). We found that this protein remains in the nucleus of cells in the ischemic focus, even $24 \mathrm{hr}$ after reoxygenation (Fig. $6 C)$. Furthermore, we could neither detect any DNA condensation in DAPI staining, nor did we observe any abnormal Nissl staining (Fig. 5E). Together, these data indicated that ischemia causes a translocation of some factors regulating pre-mRNA splicing but does not affect the nuclear integrity. 
A
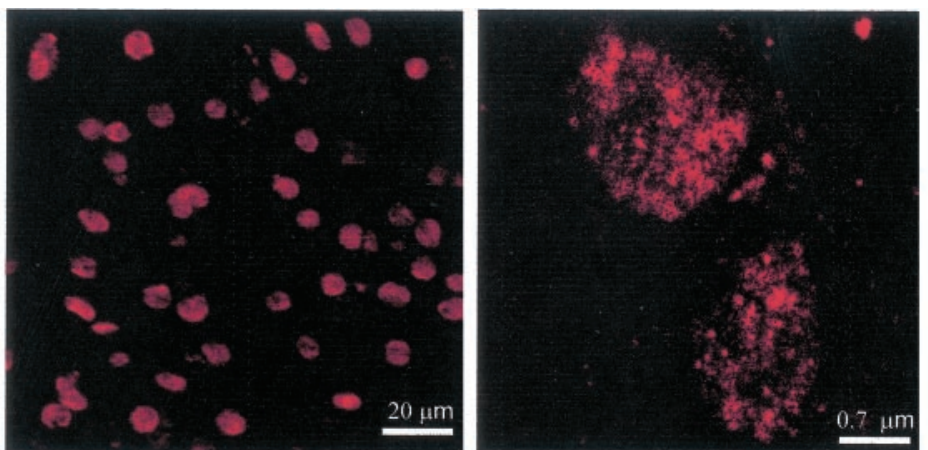

Oh
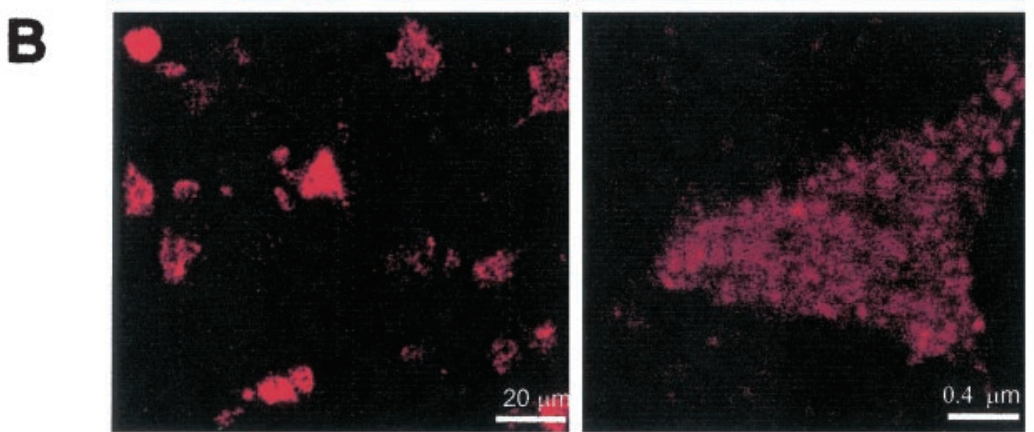

$3 h$

Figure 5. tra2- $\beta 1$ protein changes its intracellular localization after ischemia. The ischemic focus after $0,3,6$, and $24 \mathrm{hr}$ of recirculation after the occlusion, stained with the tra2- $\beta 1$ antiserum $(A-D)$, is shown. The cells were taken from the periphery of the ischemic focus. The left column shows an overview of the affected area at lower magnification. On the right, representative cell nuclei are enlarged to show the subcellular tra2- $\beta 1$ distribution. At the end of the $1 \mathrm{hr}$ ischemic interval ( $0 \mathrm{hr}$ of recirculation), the speckled pattern of tra2- $\beta 1$ is clearly visible. Twentyfour hours after ischemia, the protein is removed from the nucleus. Arrowheads in $D$ indicate protein that is present in neurites of cells. $E$, Cells of the ischemic focus are counterstained with Nissl stain (center) to demonstrate the cytoplasmatic localization or tra2- $\beta 1$ (overlay of Nissl and tra2- $\beta 1$ stain, right). Nissl stain binds to RNA present in the nucleus.
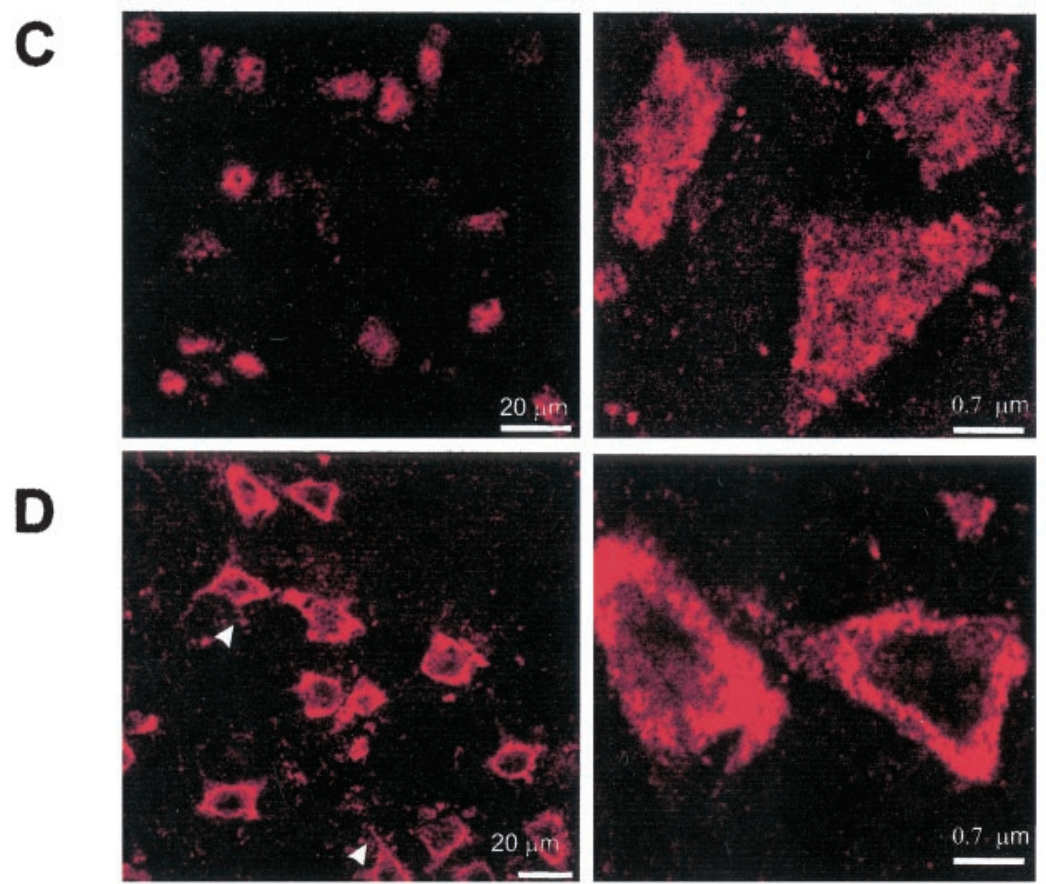

\section{$6 \mathrm{~h}$}
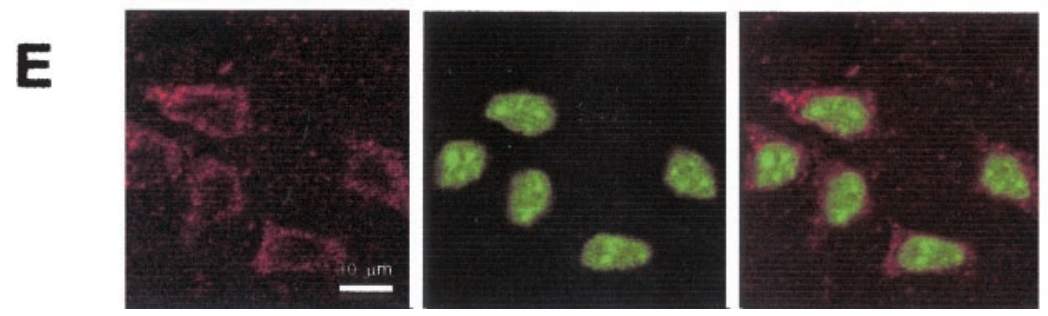

We then asked whether the changes we observed were caused by cell death and tested the expression of cleaved caspase-3, a marker for apoptosis. As shown in Figure 7, in the entire ischemic focus, only a few cells could be detected expressing this marker, which is in agreement with the data obtained in cell culture. In

contrast, tra2- $\beta 1$ and SR protein localization is strongly affected in this area, because approximately one-half the nuclei are depleted from tra2- $\beta 1$ (Fig. 3D). Furthermore, we did not observe any abnormal Nissl staining (Fig. $5 E$ ). Our results indicate that the observed change in subcellular localization is not caused by cell 

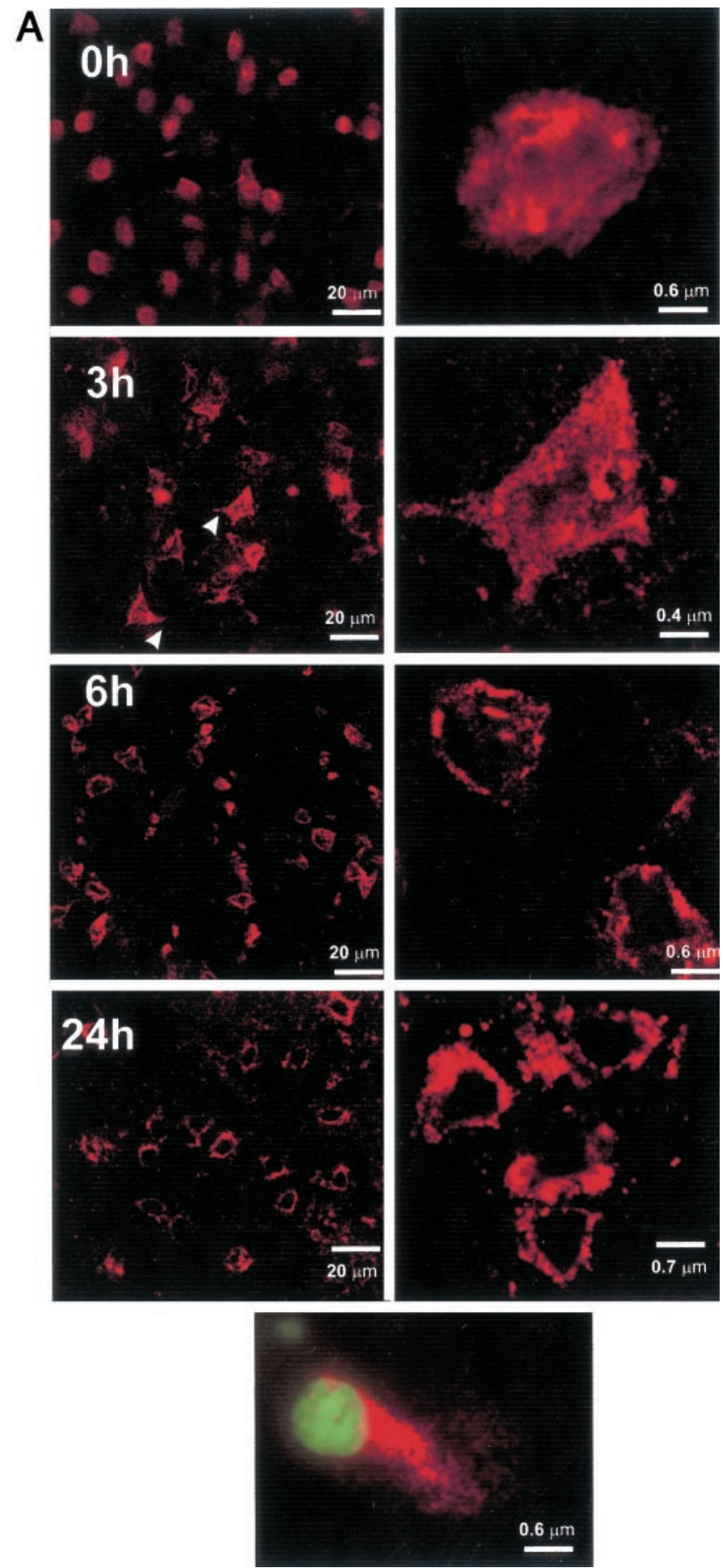

Figure 6. Intracellular localization of tra2- $\beta 1$ interacting proteins after ischemia. The left column shows an overview of the affected area at lower magnification. The area analyzed is from the periphery of the ischemic focus. On the right, representative cell nuclei are enlarged to show the subcellular distribution. $A$, Detection of SR proteins with mAb104 in the ischemic focus. The arrowheads in A ( $3 h)$ show the staining in neurites. $B$, Detection of SAM68 with anti-SAM68 antiserum in the ischemic focus. $C$, Detection of rSLM-2 in the ischemic focus.

death and the subsequent necrosis of the tissue. Similar results were seen at all other time points and with terminal deoxynucleotidyl transferase-mediated biotinylated UTP nick end labeling (TUNEL) staining (data not shown).
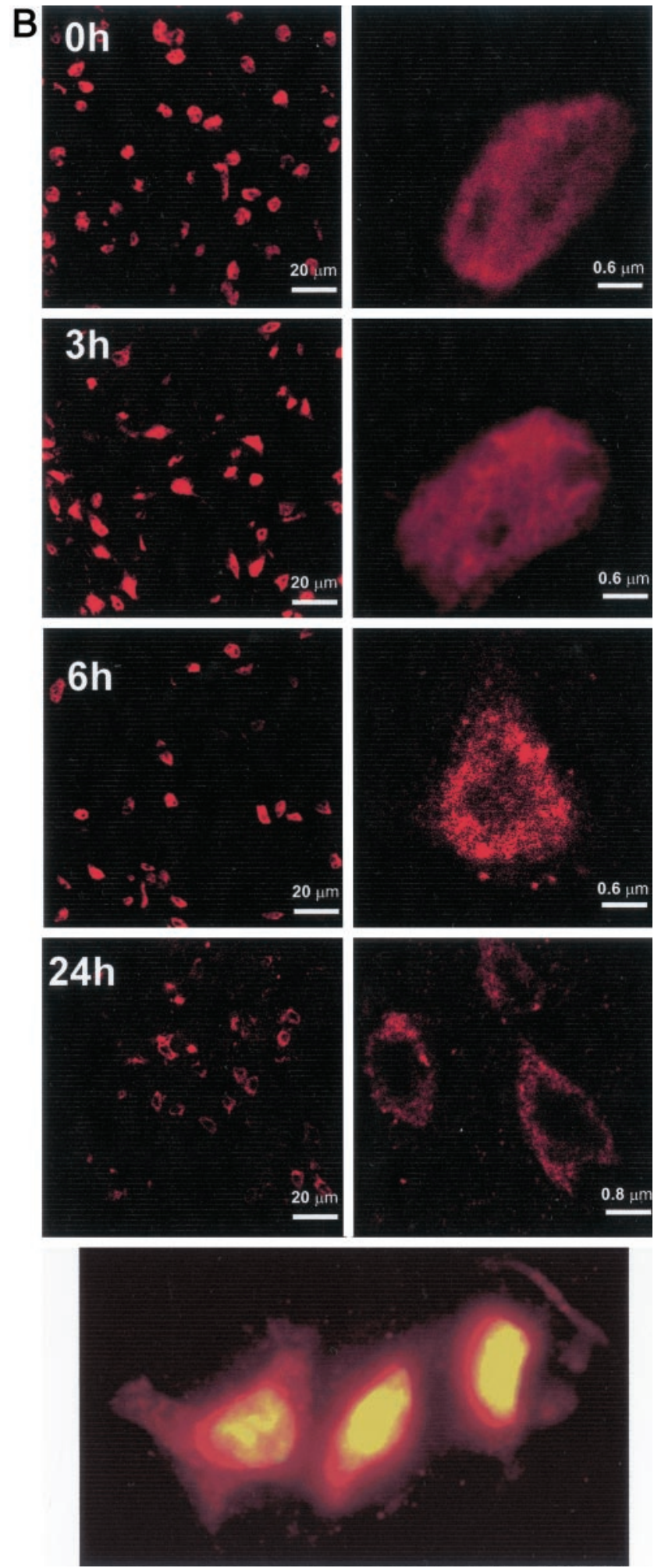

Figure 6 continues.

We conclude that some but not all proteins interacting with tra2- $\beta 1$ change their subcellular localization after transient ischemia.

\section{The alternative splicing pattern of $\mathrm{ICH}-1$ changes after ischemia}

SR proteins can change splice-site selection in a concentrationdependent manner (Manley and Tacke, 1996). We investigated 

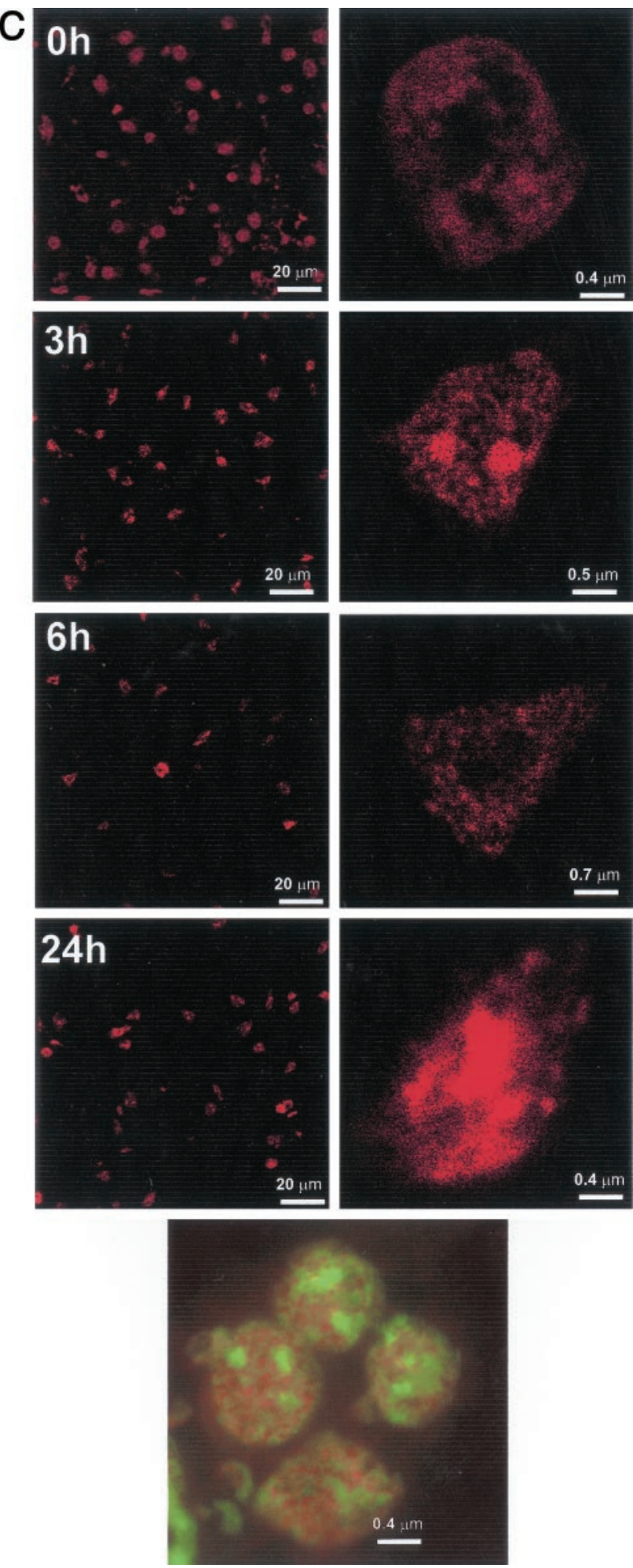

Figure 6 continued.

whether the change in nuclear SR protein concentration is concomitant with a change in splice-site selection. We isolated tissue from the ischemic area and from the contralateral control side and performed RT-PCR. The ischemic focus was identified by the lack of ATP in adjacent sections (Fig. 3). We tested the $\mathrm{ICH}-1$ gene that can generate two isoforms, ICH-1L, which promotes apoptosis, and ICH-1S, which prevents apoptosis (Wang et al., 1994), which is observed as a late effect of ischemia (Dirnagl et al., 1999). Again in agreement with the situation in culture, the ischemic episode stimulates inclusion of the alternative exon, which promotes the formation of the ICH-1S form (Fig. 8).

We conclude that concomitant with a decrease in nuclear concentration of splicing factors, alternative splice-site selection is changed in an ischemic focus.

\section{DISCUSSION}

\section{Proteins regulating pre-mRNA processing change their} subcellular localization after ischemia

We demonstrated that splicing regulatory proteins changes their intracellular localization in the brain after this tissue has been subjected to ischemia. These findings are physiologically relevant, because we relied on the analysis of endogenous proteins in cells of intact tissue. Our results are in agreement with previous studies that used overexpressed proteins in transformed cells that were subjected to osmotic shock (van der Houven van Oordt et al., 2000). We observed relocalization of tra2- $\beta 1$, SR proteins, and SAM68 to the cytoplasma. Based on the morphology, the cells where the translocation occurred were most likely neurons. Several lines of evidence indicated that this relocalization was an active process and not the result of a nonspecific breakdown of the nuclear envelope. First, some factors, such as rSLM-2, were not relocating to the cytosol; second, ribosomal RNA complexes present in the nucleus did not change their localization; and third, no evidence of apoptosis, either by cleaved caspase-3 or by TUNEL staining, was observed. The most likely explanation of our findings is that after ischemia, either the nuclear import pathways were blocked or the nuclear export was increased. The change in subcellular localization of tra2- $\beta 1$ was concomitant with hyperphosphorylation. It remains to be established whether this change in phosphorylation was the cause or the consequence of a change in subcellular localization. Similar results were observed when the influence of cellular stress, evoked by osmotic shock, was studied on hnRNP A1 (van der Houven van Oordt et al., 2000). Both tra2- $\beta 1$ and hnRNP A1 accumulate in the cytosol after being hyperphosphorylated. Because both proteins bind to transportin SR and transportin (Kataoka et al., 1999) (our unpublished data), a modulation of these systems by phosphorylation after ischemia is an interesting hypothesis that remains to be tested.

The signal-transduction pathways leading to a change in splicing factor phosphorylation are not clear. In contrast to cellular events after osmotic shock (Kataoka et al., 1999; van der Houven van Oordt et al., 2000), ischemia does not activate the MKK-p38 pathway in the brain.

Blockage of the calcium reuptake into the endoplasmatic reticulum of primary neuronal cultures has effects similar to those of ischemia. It is well established that the cytoplasmatic calcium concentration increases after an ischemic insult, and in the culture system, we found relocalization of tra2- $\beta 1$ to the cytosol. It is therefore likely that several independent pathways exist that ultimately converge on the kinases that phosphorylate hnRNP A1 and tra2- $\beta 1$.

\section{Splice-site selection is changed after ischemia}

The current model of alternative splice-site selection assumes that SR proteins and hnRNPs form a network across the premRNA that identifies exons (Wu and Maniatis, 1993; Manley and Tacke, 1996; Hertel and Maniatis, 1998; Stoss et al., 2000; Hast- 

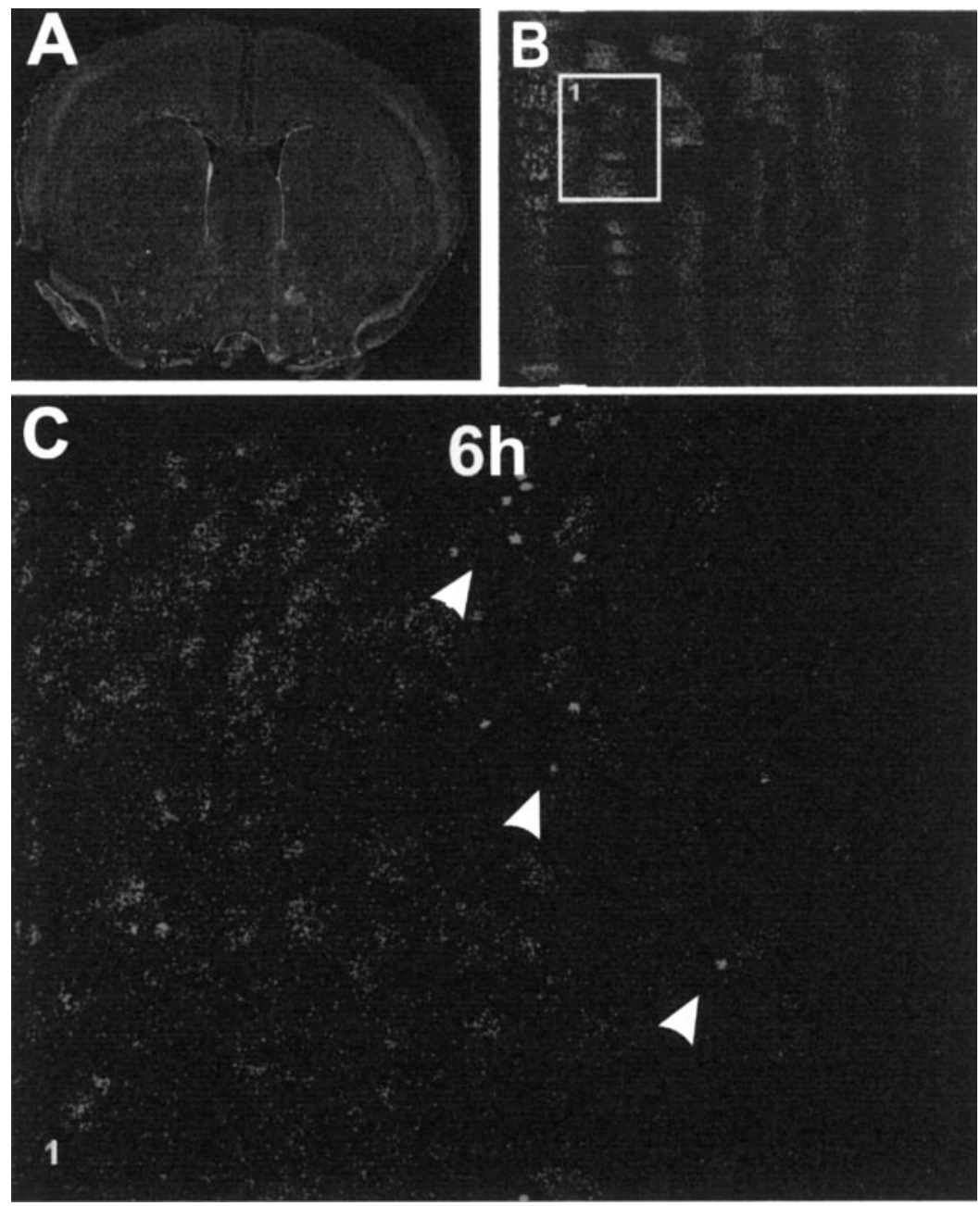

Figure 7. The apoptotic marker cleaved caspase-3 is present in only a few cells in the ischemic focus. $A$, DAPI staining of a coronal section, including the ischemic focus (i.e., the left caudate putamen). The section shown is from an animal subjected to $1 \mathrm{hr}$ of focal cerebral ischemia and then $6 \mathrm{hr}$ of recirculation. $B$, Immunostaining of a parallel section with an antiserum recognizing the cleaved caspase- 3 product. The box shows the area that is enlarged in $C$. $C$, Enlargement of the area marked in $B$. Cells expressing cleaved caspase- 3 are indicated with arrowheads. ings and Krainer, 2001), which is reflected by their ability to regulate splice-site usage in a concentration-dependent manner (Cáceres et al., 1994; Wang and Manley, 1995). The effect of SR protein kinases on splice-site selection has been attributed to a recruitment of SR proteins from their nuclear storage sites, the speckles, and a subsequent increase in nuclear SR protein concentration (Stojdl and Bell, 1999; Misteli, 2000). Because the relocation of tra2- $\beta 1$ and SR proteins to the cytosol will decrease its concentration relative to other factors regulating splice-site selection, we tested the ICH-1 pre-mRNAs that undergo alternative splicing in the brain.

We observed an increase in inclusion of the $61 \mathrm{bp}$ alternative exon of ICH-1. An increase in the SR protein SC35 and SF2/ASF concentration was shown to promote skipping of the $61 \mathrm{bp}$ alternative exon of ICH-1 (Jiang et al., 1998). Therefore, the increase in usage of this exon after ischemia could be explained by the relocation of SR proteins from the nucleus to the cytosol. The effects on RNA splicing seem to be specific, because the splicing patterns of several mRNAs were not changed. For example, alternative splicing patterns of $\mathrm{Bax}, \mathrm{Bcl}$, and $S E R C A 2$ genes were not affected. Furthermore, we did not observe an increase in RNA degradation (data not shown). The twofold to threefold changes in exon usage were comparable with the effects seen in other systems that have investigated endogenous mRNAs (Kaufer et al., 1998; Daoud et al., 1999; Xie and Black, 2001). Changes of this magnitude are physiologically relevant; for example, a 1.8- fold increase in prothrombin pre-mRNA can cause human disease (Gehring et al., 2001). In several systems studied (e.g., drug-induced increase in neuronal activity and stress evoked by forced swimming) (Kaufer et al., 1998; Daoud et al., 1999), a change in alternative splice-site selection was found as a molecular mechanism to memorize an external stimulus. Because tra2- $\beta 1$ acts on several pre-mRNAs containing purine-rich enhancers (P. Stoilov, R. Daoud, O. Nayler, and S. Stamm, unpublished observations), it is likely that the translocation of tra2- $\beta 1$ in cells affected by ischemia will orchestrate a coordinate change in alternative splice-site selection of several genes that will add to the long-term effect observed after ischemia.

We conclude that cells are able to increase the concentration of splicing regulatory proteins by recruiting them from nuclear storage sites and are able to decrease their concentration in the nucleus by transporting them to the cytosol. Because splice-site selection is dependent on the relative concentration of splicing regulatory proteins, pre-mRNA splicing patterns of some genes are changed as a result.

\section{Regulation of splice-site selection by subcellular localization of regulatory proteins}

To our knowledge, this is the first report demonstrating a change in subcellular localization of endogenous proteins regulating splice-site selection in intact tissue. To determine possible molecular mechanisms, we investigated whether a change in the intra- 

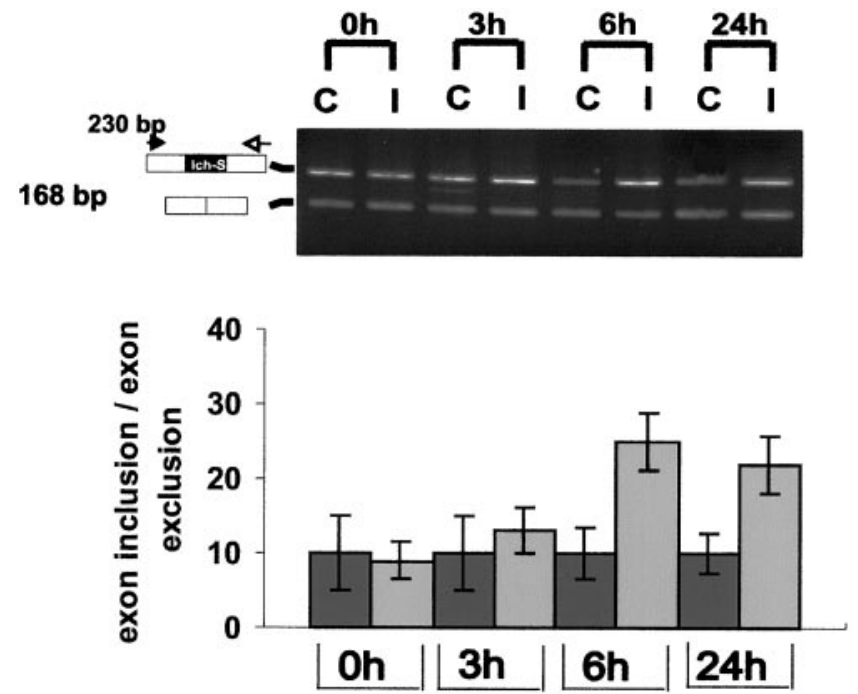

Figure 8. Change of alternative splicing pattern of the $\mathrm{ICH}-1$ gene after ischemia. RT-PCR analysis of the $\mathrm{ICH}^{-1}$ (Wang et al., 1994) gene. The tissue from the ischemic focus $(I)$ was localized with tra2- $\beta 1$ immunocytochemistry and ATP content in parallel sections. It was then separated from unaffected tissue, and its RNA was subjected to RT-PCR. As a control $(C)$, the contralateral side was used. Tissue probes were sampled from an animal subjected to $1 \mathrm{hr}$ of ischemia and then $0,3,6$, and $24 \mathrm{hr}$ of recirculation. A representative agarose gel of the RT-PCR products is on the left. The drawing on the left shows schematically the primer localization and the structure of the PCR products. The time points of recirculation are indicated at the top. The statistical evaluation of independent experiments is shown in the bottom panel. Error bars indicate the SD from at least four different experiments.

cellular calcium concentration had an effect that is comparable with ischemia. We blocked intracellular calcium reuptake and observed a change in the subcellular distribution of regulatory proteins in cultured cortical neurons. Interestingly, alternative splicing patterns of the $\mathrm{ICH}-1$ gene parallel the situation in the ischemic brain. This suggests that the calcium concentration could be part of the cascade connecting ischemia to changes in pre-mRNA splicing.

There is now increasing evidence that external stimuli can regulate pre-mRNA processing. Some of these stimuli are within the physiological range. For example, stress induced by forced swimming in mice increases the intercellular calcium concentrations and changes the alternative splicing patterns of the acetylcholine esterase gene (Kaufer et al., 1998; Grisaru et al., 1999). Other nonphysiological stimuli (e.g., neuronal activity in models of epilepsy) (Vezzani et al., 1995; Daoud et al., 1999), potassium stimulation of cultured cells (Xie and Black, 2001), and osmotic (van der Houven van Oordt et al., 2000) and temperature shock (Takechi et al., 1994; Bournay et al., 1996; Ars et al., 2000) can also result in a change in alternative splicing pathways. However, the signal-transduction pathways that mediate these changes are just beginning to emerge. The effects of potassium stimulation are mediated by calcium/calmodulin-dependent protein kinase IV (Xie and Black, 2001), which also suggests a role of intracellular calcium in splice-site regulation.

Phosphorylation was shown to release splicing factors from their internuclear storage sites, the speckles (Misteli, 2000), but under these experimental conditions, no accumulation of splicing factors in the cytosol was observed. We suggest that accumulation of splicing factors in the cytosol is a second mechanism to regulate the internuclear concentration of those proteins, which in turn can affect splice-site selection. It is likely that in most physiological stimulations, the change in subcellular localization will not be as dramatic as in ischemia, where nuclei are depleted from some splicing factors. Furthermore, it is possible that these proteins fulfill roles in the cytosol that need to be determined. Because $47-60 \%$ of all human genes are alternatively spliced (Lander et al., 2001; Modrek et al., 2001), regulation of splice-site selection is emerging as an important mechanism to regulate gene expression. In the future, DNA chip analysis will show what subset of exons is regulated by the decrease in nuclear tra2- $\beta 1$ concentration and the identification of splicing-related signaltransduction pathways will offer the opportunity for drug design in ischemia.

\section{REFERENCES}

Akker SA, Smith PJ, Chew SL (2001) Nuclear post-transcriptional control of gene expression. J Mol Endocrinol 27:123-131.

Ars E, Serra E, de la Luna S, Estivill X, Lazaro C (2000) Cold shock induces the insertion of a cryptic exon in the neurofibromatosis type 1 (NF1) mRNA. Nucleic Acids Res 28:1307-1312.

Beil B, Screaton G, Stamm S (1997) Molecular cloning of htra2-beta-1 and htra2-beta-2, two human homologues of tra-2 generated by alternative splicing. DNA Cell Biol 16:679-690.

Bournay A-S, Hedley PE, Maddison A, Waugh R, Machray GC (1996) Exon skipping induced by cold stress in a potato invertase gene transcript. Nucleic Acids Res 24:2347-2351.

Cáceres J, Stamm S, Helfman DM, Krainer AR (1994) Regulation of alternative splicing in vivo by overexpression of antagonistic splicing factors. Science 265:1706-1709.

Cáceres JF, Screaton GR, Krainer AR (1998) A specific subset of SR proteins shuttles continuously between the nucleus and the cytoplasm. Genes Dev 12:55-66.

Chew SL, Lui H-X, Mayeda A, Krainer AR (1999) Evidence for the function of an exonic splicing enhancer after the first catalytic step of pre-mRNA splicing. Proc Natl Acad Sci USA 96:10655-10660.

Chomczynski P, Sacchi N (1987) Single-step method of RNA isolation by acid guanidinium thiocyanate/phenol/chloroform extraction. Anal Biochem 162:156-159.

Corden JL, Patturajan M (1997) A CTD function linking transcription to splicing. Trends Biochem Sci 413-419.

Daoud R, Berzaghi M, Siedler F, Hübener M, Stamm S (1999) Activity dependent regulation of alternative splicing patterns in the rat brain. Eur J Neurosci 11:788-802.

Daoud R, Stoilov P, Stoss O, Hübener M, Berzaghi DP, Hartmann AM, Olbrich M, Stamm S (2000) Control of pre-mRNA processing by extracellular signals: from molecular mechanisms to clinical applications. Gene Ther Mol Biol 5:141-150.

Di Fruscio M, Chen T, Richard S (1999) Characterization of Sam68-like mammalian proteins SLM-1 and SLM-2: SLM-1 is a Src substrate during mitosis. Proc Natl Acad Sci USA 96:2710-2715.

Dirnagl U, Iadecola C, Moskowitz MA (1999) Pathobiology of ischaemic stroke: an integrated view. Trends Neurosci 22:391-397.

Elliot DJ (2000) Splicing and the single cell. Histol Histopathol $15: 239-249$

Fu X-D (1995) The superfamily of arginine/serine-rich splicing factors. RNA 1:663-680.

Gehring NH, Frede U, Neu-Yilik G, Hundsdörfer P, Vetter B, Hentze MW, Kulozik AE (2001) Increased efficiency of mRNA 3' end formation: a new genetic mechanism contributing to hereditary thrombophilia. Nat Genet 28:389-392.

Grabowski P (1998) Splicing regulation in neurons: tinkering with cellspecific control. Cell 92:709-712.

Grabowski PL, Black DL (2001) Alternative RNA splicing in the nervous system. Prog Neurobiol 65:289-308.

Graveley BR (2000) Sorting out the complexity of SR protein function. RNA 6:1197-1211.

Grisaru D, Sternfeld M, Eldor A, Glick D, Soreq H (1999) Structural roles of acetylcholineesterase variants in biology and pathology. Eur J Biochem 264:672-686.

Grondahl TO, Hablitz JJ, Langmoen IA (1998) Depletion of intracellular $\mathrm{Ca}^{2+}$ stores or lowering extracellular calcium alters intracellular $\mathrm{Ca}^{2+}$ changes during cerebral energy deprivation. Brain Res 796: $125-132$.

Gyngell ML, Busch E, Schmitz B, Kohno K, Back T, Hoehnberlage M, Hossmann K-A (1995) Evolution of acute focal cerebral ischaemia in rats observed by localized H-1 MRS, diffusion-weighted MRI, and electrophysiological monitoring. NMR Biomed 8:206-214.

Hanamura A, Cáceres JF, Mayeda A, Franza BR, Krainer AR (1998) 
Regulated tissue-specific expression of antagonistic pre-mRNA splicing factors. RNA 4:430-444.

Hara H, Huang PL, Panahian N, Fishman MC (1996) Reduced brain edema and infarction volume in mice lacking the neuronal isoform of nitric oxide synthase after transient MCA occlusion. J Cereb Blood Flow Metab 16:605-611.

Hastings ML, Krainer AR (2001) Pre-mRNA splicing in the new millennium. Curr Opin Cell Biol 13:302-309.

Hata R, Mies G, Wiessner C, Fritze K, Hesselbarth D, Brinker G, Hossmann K-A (1998) A reproducible model of middle cerebral artery occlusion in mice: hemodynamic, biochemical and magnetic resonance imaging. J Cereb Blood Flow Metab 18:367-375.

Heiss W-D, Graf R, Wienhard K, Lottgen J, Saito R, Fujita T, Rosner G, Wagner R (1994) Dynamic penumbra demonstrated by sequential multitracer PET after middle cerebral artery occlusion in cats. J Cereb Blood Flow Metab 14:892-902.

Hertel KJ, Maniatis T (1998) The function of multisite splicing enhancers. Mol Cell 1:449-455.

Hertel KJ, Lynch KW, Maniatis T (1997) Common themes in the function of transcription and splicing enhancers. Curr Opin Cell Biol 9:350-357.

Hodges PE, Carrico PM, Hogan JD, O’Neill KE, Owen JJ, Mangan M, Davis BP, Brooks JE, Garrels JI (2002) Annotating the human proteome: the Human Proteome Survey Database (HumanPSD) and an in-depth target database for $\mathrm{G}$ protein-coupled receptors (GPCR-PD) from Incyte Genomics. Nucleic Acids Res 30:137-141.

Hossmann K-A (1994) Viability thresholds and the penumbra of focal ischemia. Ann Neurol 36:557-565.

Jiang H-H, Zhang W-J, Rao Y, Wu JY (1998) Regulation of Ich-1 pre-mRNA alternative splicing and apoptosis by mammalian splicing factors. Proc Natl Acad Sci USA 95:9155-9160.

Kamma H, Portman DS, Dreyfuss G (1995) Cell type-specific expression of hnRNP proteins. Exp Cell Res 221:187-196.

Kataoka N, Bachorik JL, Dreyfuss G (1999) Transportin-SR, a nuclear import receptor for SR proteins. J Cell Biol 145:1145-1152.

Kaufer D, Friedman A, Seidman S, Soreq H (1998) Acute stress facilitates long-lasting changes in cholinergic gene expression. Nature 393:373-377.

Kogure K, Alonso OF (1978) A pictorial representation of endogenous brain ATP by a bioluminescent method. Brain Res 154:273-284.

Laemmli UK (1970) Cleavage of structural proteins during the assembly of the head of bacteriophage T4. Nature 227:680-685.

Lander ES, Linton LM, Birren B, Nusbaum C, Zody MC, Baldwin J, Devon K, Dewar K, Doyle M, FitzHugh W, Funke R, Gage D, Harris K, Heaford A, Howland J, Kann L, Lehoczky J, LeVine R, McEwan P, McKernan K, et al (2001) Initial sequencing and analysis of the human genome. Nature 409:860-921.

Liu HX, Zhang M, Krainer AR (1998) Identification of functional exonic splicing enhancer motifs recognized by individual SR proteins. Genes Dev 12:1998-2012.

Liu HX, Chew SL, Cartegni L, Zhang MQ, Krainer AR (2000) Exonic splicing enhancer motif recognized by human SC35 under splicing conditions. Mol Cell Biol 20:1063-1071.

Manley JL, Tacke R (1996) SR proteins and splicing control. Genes Dev 10:1569-1579.

McBride AE, Schlegel A, Kirkegaard K (1996) Human protein Sam68 relocalization and interaction with poliovirus RNA polymerase in infected cells. Proc Natl Acad Sci USA 93:2296-2301.

McCracken S, Fong N, Yankulov K, Ballantyne S, Pan G, Greenblatt J, Patterson SD, Wickens M, Bentley DL (1997) The C-terminal domain of RNA polymerase II couples mRNA processing to transcription. Nature 385:357-361.

Misteli T (2000) Cell biology of transcription and pre-mRNA splicing: nuclear architecture meets nuclear function. J Cell Sci 113:1841-1849.

Modrek B, Resch A, Grasso C, Lee C (2001) Genome-wide detection of alternative splicing in expressed sequences of human genes. Nucleic Acids Res 29:2850-2859.

Nayler O, Stamm S, Ullrich A (1997) Characterization and comparison of four serine- and arginine-rich (SR) protein kinases. Biochem $\mathrm{J}$ 326:693-700.

Nayler O, Cap C, Stamm S (1998a) Human transformer-2-beta gene (SFRS10): complete nucleotide sequence, chromosomal localization, and generation of a tissue-specific isoform. Genomics 53:191-202.

Nayler O, Strätling W, Bourquin J-P, Stagljar I, Lindemann L, Jasper H, Hartmann AM, Fackelmayer FO, Ullrich A, Stamm S (1998b) SAF-B couples transcription and pre-mRNA splicing to SAR/MAR elements. Nucleic Acids Res 26:3542-3549.

Neugebauer KM, Stolk JA, Roth MB (1995) A conserved epitope on a subset of SR proteins defines a larger family of pre-mRNA splicing factors. J Cell Biol 129:899-908.

Paschen W, Doutheil J, Gissel C, Treiman M (1996) Depletion of neuronal endoplasmic reticulum calcium stores by thapsigargin: effect on protein synthesis. J Neurochem 67:1735-1743.

Smith CW, Valcarcel J (2000) Alternative pre-mRNA splicing: the logic of combinatorial control. Trends Biochem Sci 25:381-388.

Soreq H, Seidman S (2001) Acetylcholinesterase-new roles for an old actor. Nat Rev Neurosci 2:294-302.

Stamm S, Casper D, Lees-Miller JP, Helfman DM (1993) Brain-specific tropomyosins TMBr-1 and TMBr-3 have distinct patterns of expression during development and in adult brain. Proc Natl Acad Sci USA 90:9857-9861.

Stojdl DF, Bell JC (1999) SR protein kinases: the splice of life. Biochem Cell Biol 77:293-298.

Stoss O, Stoilov P, Daoud R, Hartmann AM, Olbrich M, Stamm S (2000) Misregulation of pre-mRNA splicing that causes human diseases. Gene Ther Mol Biol 5:9-28.

Stoss O, Olbrich M, Hartmann AM, König H, Memmott J, Andreadis A, Stamm S (2001) The STAR/GSG family protein rSLM-2 regulates the selection of alternative splice sites. J Biol Chem 276:8665-8673.

Takechi H, Hosokawa N, Hirayoshi K, Nagata K (1994) Alternative 5 splice site selection induced by heat shock. Mol Cell Biol 14:567-575.

Taylor SJ, Anafi M, Pawson T, Shalloway D (1995) Functional interaction between c-src and its mitotic target, Sam68. J Biol Chem 270:10120-10124.

Taylor TN, Davis PH, Torner JC, Holmes J, Meyer JW, Jacobson MF (1996) Lifetime cost of stroke in the United States. Stroke 27:1459-1466.

Tian M, Maniatis T (1993) A splicing enhancer complex controls alternative splicing of doublesex pre-mRNA. Cell 74:105-114.

Treiman M, Casperson C, Christensen S (1998) A tool coming of age: thapsigargin as an inhibitor of sarco-endoplasmatic reticulum $\mathrm{Ca}^{++}$ ATPases. Trends Pharmacol Sci 19:131-135.

Trendelenburg G, Muselmann C, Prass K, Ruscher K, Polley A, Wiegand F, Meisel A, Rosenthal A, Dirnagl U (2000) Reproducibility of seria analysis of gene expression (SAGE) and comprehensive transcript profiling in focal cerebral ischemia in the mouse. Eur J Neurosci 12 [Suppl 11]:307.

van der Houven van Oordt W, Diaz-Meco MT, Lozano J, Krainer AR, Moscat J, Cáceres JF (2000) The MKK 3/6-p38-signaling cascade alters the subcellular distribution of hnRNPA1 and modulates alternative splicing regulation. J Cell Biol 149:307-316.

Venables JP, Vernet C, Chew SL, Elliott DJ, Cowmaedow RB, Wu J, Cooke HJ, Artzt K, Eperon IC (1999) T-STAR/ETOILE: a nove relative of SAM68 that interacts with an RNA-binding protein implicated in spermatogenesis. Hum Mol Genet 8:959-969.

Venables JP, Elliott DJ, Makarova OV, Makarova EM, Cooke HJ, Eperon IC (2000) RBMY, a probable human spermatogenesis factor, and other hnRNP G proteins interact with Tra2beta and affect splicing. Hum Mol Genet 9:685-694.

Vernet C, Artzt K (1997) STAR, a gene family involved in signal transduction and activation of RNA. Trends Genet 13:479-484.

Vezzani A, Speciale C, Vedova FD, Tamburin M, Benatti L (1995) Alternative splicing at the C-terminal but not the N-terminal domain of the NMDA receptor NR1 is altered in the kindled hippocampus. Eur J Neurosci 7:2513-2517.

Wang J, Manley JL (1995) Overexpression of the SR proteins ASF/SF2 and SC35 influences alternative splicing in vivo in diverse ways. RNA $1: 335-346$.

Wang L, Miura M, Bergeron L, Zhu H, Yuan J (1994) Ich-1, an Ice/ced3 -related gene, encodes both positive and negative regulators of programmed cell death. Cell 78:739-750.

Weighardt F, Biamonti G, Riva S (1996) The role of heterogeneous nuclear ribonucleoproteins (hnRNP) in RNA metabolism. BioEssays 18:747-756.

Wu JY, Maniatis T (1993) Specific interactions between proteins implicated in splice site selection and regulated alternative splicing. Cell 75:1061-1070.

Xie J, Black DL (2001) A CaMK IV responsive RNA element mediates depolarization-induced alternative splicing of ion channels. Nature 410:936-939. 